Rabaska

Revue d'ethnologie de l'Amérique française

\title{
Louis Cyr, l'homme le plus fort du monde
}

Volume 12, 2014

URI : https://id.erudit.org/iderudit/1026791ar

DOI : https://doi.org/10.7202/1026791ar

Aller au sommaire du numéro

Éditeur(s)

Société québécoise d'ethnologie

ISSN

1703-7433 (imprimé)

1916-7350 (numérique)

Découvrir la revue

Citer ce document

(2014). Louis Cyr, l'homme le plus fort du monde. Rabaska, 12, 187-187.

https://doi.org/10.7202/1026791ar

Ce document est protégé par la loi sur le droit d'auteur. L'utilisation des services d'Érudit (y compris la reproduction) est assujettie à sa politique d'utilisation que vous pouvez consulter en ligne.

https://apropos.erudit.org/fr/usagers/politique-dutilisation/
Cet article est diffusé et préservé par Érudit.

Érudit est un consortium interuniversitaire sans but lucratif composé de l'Université de Montréal, l'Université Laval et l'Université du Québec à Montréal. Il a pour mission la promotion et la valorisation de la recherche. https://www.erudit.org/fr/ 


\section{Place publique}

Points de vue / film

\section{Louis Cyr, l'homme le plus fort du monde}

Louis Cyr, l'homme le plus fort du monde. Film réalisé par Daniel Roby, scénarisé par Sylvain Guy, produit par Christian Larouche et distribué par Les Films Séville Inc., 130 minutes, 2013.

Cyprien-Noé Cyr naît le 10 octobre 1863 à Saint-Cyprien-de-Napierville, au Québec. Le 16 janvier 1882, il épouse Mélina Comtois à Saint-Jean-de-Matha et décède à Montréal le 10 novembre 1912. Il est inhumé à Saint-Jean-deMatha où l'on peut voir un monument érigé à son effigie au centre-ville. En 1878, la famille Cyr émigre aux États-Unis et s'installe à Lowell, dans le Massachusetts. C'est durant son séjour à Lowell que Cyprien-Noé change ses prénoms pour celui de Louis. À 17 ans, le jeune Cyr pèse quelque 230 livres. Il aime lever des poids et haltères ainsi qu'à faire étalage de sa force. Vers l'âge de 18 ans, il participe à son premier concours d'hommes forts à Boston, où

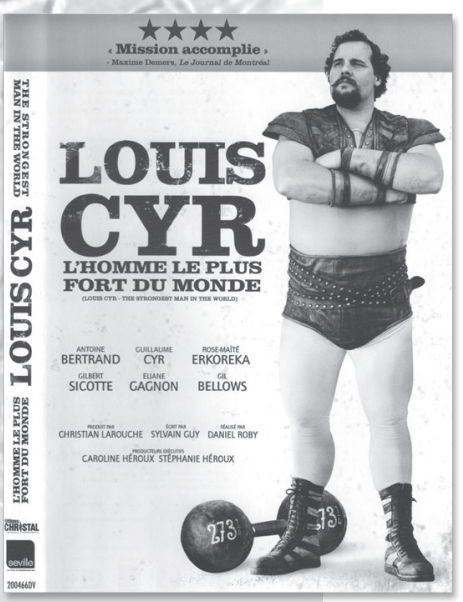

il réussit à lever un cheval de terre. Louis Cyr amorce alors une carrière d'homme fort qui le rendra célèbre. Rabaska a demandé à trois collaborateurs de croiser leur point de vue sur ce film qui a rempli les salles de cinéma du Québec depuis sa sortie publique le 12 juillet 2013. Il s'agit de Bertrand Bergeron, professeur retraité du collège d'Alma au Lac-Saint-Jean, de Robert Perreault, professeur au Saint Anselm College de Manchester au NewHampshire, et de Dean Louder, professeur retraité de géographie à l'Université Laval. 